\title{
Honokiol exerts an anticancer effect in T98G human glioblastoma cells through the induction of apoptosis and the regulation of adhesion molecules
}

\author{
JAE JU JEONG, JAE HEUN LEE, KI CHURL CHANG and HYE JUNG KIM \\ Department of Pharmacology, School of Medicine and Institute of Health Sciences, \\ Gyeongsang National University, Jinju, Republic of Korea
}

Received March 13, 2012; Accepted May 25, 2012

DOI: $10.3892 /$ ijo.2012.1582

\begin{abstract}
Glioblastoma is one of the most lethal and common malignant human brain tumors, with aggressive proliferation and highly invasive properties. Honokiol derived from Magnolia officinalis is able to cross the blood-brain barrier (BBB) and the blood-cerebrospinal fluid barrier (BCSFB), suggesting a strong possibility that it could be an effective drug for the treatment of brain tumors, including glioblastoma. Thus, we investigated the effects of honokiol on the expression of adhesion molecules in TNF- $\alpha$-stimulated endothelial cells, and cancer growth and invasion were determined in T98G human glioblastoma cells. Honokiol dose-dependently inhibited the expression of intercellular adhesion molecule-1 (ICAM-1) and vascular cell adhesion molecule-1 (VCAM-1) in human umbilical vein endothelial cells (HUVECs) stimulated with TNF- $\alpha$ for $6 \mathrm{~h}$. Pretreatment with honokiol significantly reduced the adhesion of T98G cells to HUVECs. Moreover, honokiol inhibited the invasion of T98G cells, suggesting that honokiol has an anti-metastatic effect. In addition, honokiol increased the cytotoxicity of T98G cells in a dose- and timedependent manner as assayed by MTT. TUNEL assay showed that honokiol significantly induced apoptosis in T98G cells at doses of $10 \mu \mathrm{M}$ or more. The induction of apoptotic cell death
\end{abstract}

Correspondence to: Professor Hye Jung Kim, Department of Pharmacology, School of Medicine and Institute of Health Sciences, Gyeongsang National University, Jinju, Republic of Korea

E-mail: hyejungkim@gnu.ac.kr

Abbreviations: BBB, blood-brain barrier; BCSFB, blood-cerebrospinal fluid barrier; CNS, central nervous system; EC, endothelial cell; ECGS, endothelial cell growth supplements; ECL, enhanced chemiluminescence; ECM, extracellular matrix; HUVEC, human umbilical vein endothelial cell; ICAM, intercellular adhesion molecule; IL, interleukin-1; PVDF, polyvinylidene difluoride; SDS, sodium dodecyl sulfate; TBS-T, Tris-buffered saline/Tween-20; TNF, tumor necrosis factor; TUNEL, terminal deoxynucleotidyl transferase biotin-dUTP nick end labeling; VCAM, vascular cell adhesion molecule

Key words: apoptosis, honokiol, human glioblastoma, intercellular adhesion molecule-1, vascular cell adhesion molecule-1, metastasis was mediated by the downregulation of the anti-apoptotic protein Bcl-2 and the upregulation of the pro-apoptotic protein Bax. Taken together, the results of this study suggest that honokiol exerts an anticancer effect by preventing metastasis and inducing apoptotic cell death of brain tumor cells.

\section{Introduction}

Malignant gliomas account for approximately $70 \%$ of the 22,500 new cases of malignant primary brain tumor diagnosed in adults in the United States each year (1). Glioblastoma, the most common malignant primary central nervous system (CNS) glioma in adults, represents $51 \%$ of all CNS gliomas. Glioblastoma is comprised of poorly differentiated, heterogeneous neoplastic astrocytes that exhibit aggressive proliferation and highly invasive properties (2). It diffusely infiltrates various regions of the normal brain, making total surgical removal impossible; thus, patients diagnosed with glioblastoma have a poor prognosis, even in response to multidisciplinary treatment strategies including surgery, radiotherapy and chemotherapy (3). Moreover, in the case of chemotherapy, the blood-brain barrier (BBB) and the blood-cerebrospinal fluid barrier (BCSFB) hampered the effects of both conventional and targeted therapies. Therefore, for drugs to act within the brain, drugs must cross the BBB and the BCSFB.

The root and stem bark of Magnolia officinalis has been used as a folk medicine by the Chinese people for the treatment of thrombotic stroke, gastrointestinal complaints, anxiety and nervous disturbance (4). Honokiol is a well-known bioactive constituent of the bark of Magnolia officinalis and has long been known to possess antioxidant (5), antianxiolytic (6-9), and antidepressant activities (10), as well as to prevent and protect the brain from damage (11). Previous studies have shown that honokiol also demonstrated extensive antitumor efficacy in vitro and in vivo (12-15) and that treatment with honokiol was a potential strategy to overcome immunoresistance in glioma (16). According to a recent report, honokiol was able to cross the BBB and the BCSFB (17), suggesting a strong possibility that it could be an effective drug for the treatment of brain tumors, including glioblastoma.

Adhesion molecules play an important role in the inflammatory response and the interactions of cancer cells with the 
extracellular matrix (ECM). Cancer progression is a multi-step process in which some adhesion molecules, including intercellular adhesion molecule-1 (ICAM-1), vascular cell adhesion molecule-1 (VCAM-1) and E-selectin, play a pivotal role in the development of recurrent, invasive and distant metastasis. Cell adhesion molecules (CAMs) are expressed on a variety of cells, including vascular endothelial cells (ECs), lymphocytes, fibroblasts, hematopoietic cells and tumor cells (18-22), that have been activated by cytokines such as interleukin-1 $\alpha$ (IL-1 $\alpha)$, IL-6 or tumor necrosis factor- $\alpha$ (TNF- $\alpha)(23,24)$. TNF- $\alpha$, in particular, induces upregulation of ICAM-1 and VCAM-1 in ECs (25-27). ICAM-1 and VCAM-1 have been shown to be involved in cell-cell and cell-ECM interactions and are mechanistically important for the extravasation of both monocytes during inflammation (28) and cancer cells during metastasis $(29,30)$. The adhesion of circulating tumor cells to the microvascular endothelium of organs at distant sites is an important step in blood-borne metastasis.

It has been reported that honokiol possesses potent activities against CNS diseases and anti-angiogenic properties. However, to date few studies have reported on the effect of honokiol on cell death and invasion of glioblastoma. Therefore, the aim of the present study was to determine the effect of honokiol on invasion of T98G glioblastoma cells, cell death and the possible mechanisms involved.

\section{Materials and methods}

Materials. Honokiol (MW 266.33, $\mathrm{C}_{18} \mathrm{H}_{18} \mathrm{O}_{2}$, Fig. 1) was purchased from Wako Chemical (Wako, Japan). Fetal bovine serum (FBS) was purchased from Gibco-BRL (Rockville, MD). Anti-ICAM-1 and anti-VCAM-1 were purchased from Santa Cruz Biotechnology (Santa Cruz, CA). Enhanced chemiluminescence (ECL) western blotting detection reagent was purchased from Amersham (Buckinghamshire, UK). All other chemicals, including endothelial cell growth supplements (ECGS) and heparin, were purchased from Sigma-Aldrich (St. Louis, MO).

Cell culture. Human umbilical vein endothelial cells (HUVECs) were obtained from Clonetics (San Diego, CA), grown in medium 199 supplemented with 20\% FBS, $2 \mathrm{mM}$ L-glutamine, $5 \mathrm{U} / \mathrm{ml}$ heparin, $100 \mathrm{IU} / \mathrm{ml}$ penicillin, $10 \mu \mathrm{g} / \mathrm{ml}$ streptomycin and $50 \mu \mathrm{g} / \mathrm{ml}$ ECGS and incubated in a humidified $5 \% \mathrm{CO}_{2}$ incubator. HUVECs were plated at a density of $1 \times 10^{7}$ cells per $100 \mathrm{~mm}$ dish. Cells were used between passage numbers 3 and 6 .

Cell viability assay. Cell viability was determined colorimetrically using the MTT assay. Cells in the exponential phase were seeded at $1 \times 10^{4}$ cells per well in 24 -well plates. After different treatments, $20 \mu \mathrm{l}$ of $5 \mathrm{mg} / \mathrm{ml}$ MTT solution was added to each well $(0.1 \mathrm{mg} /$ well $)$, and the wells were incubated for $4 \mathrm{~h}$. The supernatants were aspirated, the formazan crystals in each well were dissolved in $200 \mu \mathrm{l}$ of dimethyl sulfoxide for $30 \mathrm{~min}$ at $37^{\circ} \mathrm{C}$, and the optical density at $570 \mathrm{~nm}$ was read on a microplate reader (Bio-Rad, Hercules, CA).

Western blot analysis. Cells were lysed in PRO-PREP protein extraction solution. The sample was centrifuged at $13000 \mathrm{rpm}$

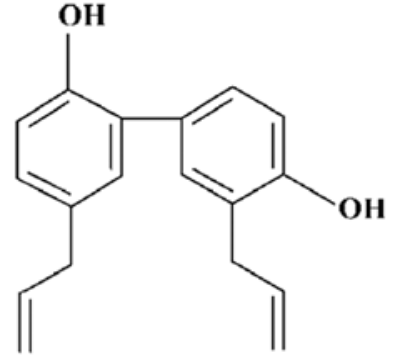

Figure 1. Chemical structure of honokiol.

for $15 \mathrm{~min}$ at $4^{\circ} \mathrm{C}$. Protein concentration was determined by the Bradford method. An equal volume of $2 \mathrm{X}$ SDS sample buffer (0.1 M Tris- $\mathrm{Cl}, 20 \%$ glycerol, $4 \%$ SDS, and $0.01 \%$ bromophenol blue) was added to an aliquot of the supernatant fraction from the lysates, and the samples were boiled for $5 \mathrm{~min}$. Aliquots of $30 \mu \mathrm{g}$ of protein were subjected to $10 \%$ SDS-polyacrylamide gel electrophoresis for $1 \mathrm{~h} 30 \mathrm{~min}$ at $110 \mathrm{~V}$. The separated proteins were transferred to a PVDF membrane for $2 \mathrm{~h}$ at $20 \mathrm{~mA}$ with the SD Semi-dry Transfer Cell (Bio-Rad). The membranes were blocked with $5 \%$ nonfat milk in Tris-buffered saline (TBS) containing $0.05 \%$ Tween-20 (TBS-T) for $2 \mathrm{~h}$ at room temperature. Then, the membranes were incubated with primary antibodies in 5\% skim milk in TBS-T overnight at $4^{\circ} \mathrm{C}$, and the bound antibody was detected by horseradish peroxidase-conjugated anti-rabbit IgG. The membranes were washed and then developed using a western blotting Luminol Reagent system (Amersham).

Adhesion assay. HUVECs were seeded into two-well chamber slides $48 \mathrm{~h}$ before the experiments. T98G cells $\left(3 \times 10^{7}\right)$ were incubated in an RPMI-1640 medium containing 2\% FBS and $10 \mathrm{mg} / \mathrm{ml}$ of the fluorescent dye BCECF/AM (Boehringer, Mannheim, Germany) at $37^{\circ} \mathrm{C}$ for $30 \mathrm{~min}$. Fluorescently labeled cells were pelleted and resuspended $\left(7.5 \times 10^{5}\right.$ cells $\left./ \mathrm{ml}\right)$ in medium 199 with $10 \mathrm{mM}$ HEPES buffer (M199H). HUVECs were washed three times with $\mathrm{M} 199 \mathrm{H}$ before the dye-loaded cells were added and incubated at $37^{\circ} \mathrm{C}$. After $30 \mathrm{~min}$, cell suspensions were withdrawn, and the HUVECs were gently washed with M199H. Fluorescent images were obtained using a high-resolution video camera (DXC-960MD; Sony) mounted on a BH-2 Olympus microscope (Melville, NY), and the immunoreactivity of these images was measured using SigmaGel 1.0 (Jandel Scientific, Germany). The analyses were repeated three times over the same region, and the results are the mean values of the three independent experiments.

Matrigel invasion assay. The Matrigel invasion assay was performed as previously described (31). Briefly, T98G cells treated with honokiol were collected, and $2 \times 10^{5}$ cells/insert in serum-free media were added to the Matrigel-coated upper chambers ( $8 \mu \mathrm{m}$ pore size, Falcon). RPMI media containing $10 \%$ FBS was added to the lower chambers, and the invasion chambers were incubated for $24 \mathrm{~h}$ in a $37^{\circ} \mathrm{C}$ cell culture incubator. The noninvasive cells that remained on the upper surface of the insert membranes were removed by scrubbing. The cells on the lower insert membranes were stained with DAPI, and the cells were counted under the light microscope. 
A

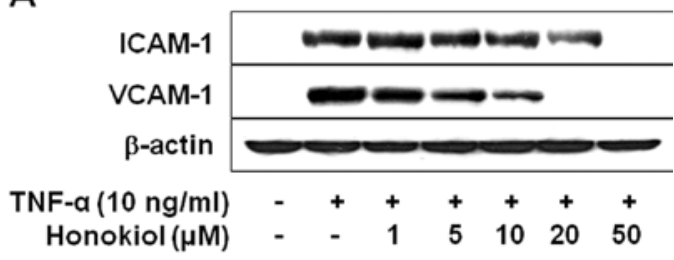

B

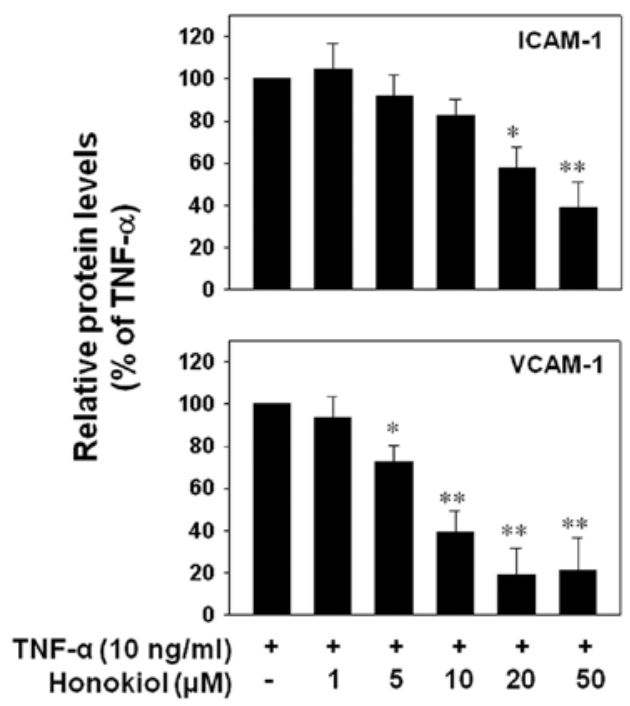

Figure 2. The inhibitory effect of honokiol on the TNF- $\alpha$-mediated induction of ICAM-1 and VCAM-1 in HUVECs. Cells were pretreated with various concentrations of honokiol $(1,5,10,20$ or $100 \mu \mathrm{M})$ for $24 \mathrm{~h}$ and then stimulated with TNF- $\alpha(10 \mathrm{ng} / \mathrm{ml})$ for $6 \mathrm{~h}$. After treatment, the protein was extracted from the cells, and (A) ICAM-1 and VCAM-1 protein levels were determined by western blot analysis. (B) Band intensities were assessed by scanning densitometry. Data are presented as the mean values \pm SD of three independent experiments. Significance compared with TNF- $\alpha,{ }^{*} \mathrm{P}<0.05,{ }^{* *} \mathrm{P}<0.01$.

Each sample was measured in triplicate, and each experiment was repeated three times.

Terminal deoxynucleotidyl transferase biotin-dUTP nick end labeling (TUNEL) assay. Cells at the exponential phase were seeded at $1 \times 10^{7}$ cells/well on a slide glass. The cells were treated with honokiol for $24 \mathrm{~h}$ at $37^{\circ} \mathrm{C}$, washed with PBS and fixed by the addition of methanol. Apoptotic cells were identified by a TUNEL assay of nucleosomal DNA fragments using a commercially available In Situ Cell Death Detection Kit (Roche, Penzberg, Germany), according to the manufacturer's protocol, with a minor modification.

Statistical evaluations. Scanning densitometry was performed using an Image Master ${ }^{\circledR}$ VDS (Pharmacia Biotech Inc., San Francisco, CA). All data are expressed as the mean \pm SD of results from the number (n) of experiments. Differences between data sets were assessed by Student's t-test. $\mathrm{P}<0.05$ indicated a statistically significant difference.

\section{Results}

Honokiol suppressed TNF- $\alpha$-induced ICAM-1 and VCAM-1 expression in HUVECs. Adhesion molecules such as ICAM-1 and VCAM-1 have been shown to be involved in cell-cell and
A
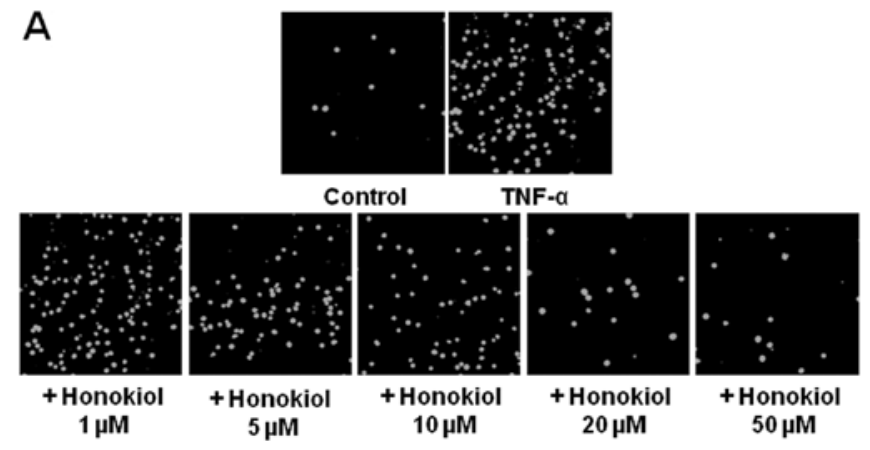

B

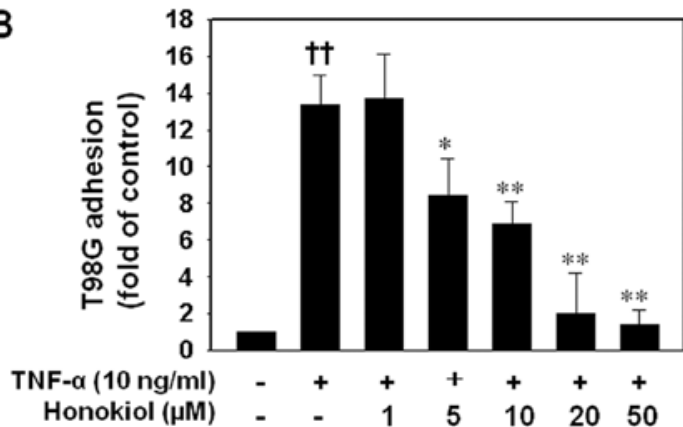

Figure 3. The inhibition of TNF- $\alpha$-stimulated adhesion of T98G cells to endothelial cells (ECs) by honokiol. HUVECs were stimulated with TNF- $\alpha$ for $6 \mathrm{~h}$ after pretreatment with or without honokiol $(1,5,10,20$, or $50 \mu \mathrm{M})$ for $24 \mathrm{~h}$. Then, cells were coincubated with fluorescently labeled T98G cells for $30 \mathrm{~min}$ at $37^{\circ} \mathrm{C}$, and $\mathrm{T} 98 \mathrm{G}$ cell adhesion to ECs is presented (A) as images or (B) as a percentage. Data represent the mean \pm SD of three separate experiments performed in triplicate. Significance compared with control, $\uparrow \uparrow \mathrm{P}<0.01$; significance compared with TNF- $\alpha,{ }^{*} \mathrm{P}<0.05,{ }^{* *} \mathrm{P}<0.05$.

cell-ECM interactions and are mechanistically important for the extravasation of cancer cells during metastasis $(1,29)$. The adhesion of circulating tumor cells to the microvascular endothelium of organs at distant sites is an important step in blood-borne metastasis. Accordingly, we first examined the effect of honokiol on ICAM-1 and VCAM-1 expression after TNF- $\alpha$-stimulation of HUVECs. The cells were pretreated with varying doses of honokiol $(1,5,10,20$ or $50 \mu \mathrm{M})$ for $24 \mathrm{~h}$ and were then co-treated with TNF- $\alpha(10 \mathrm{ng} / \mathrm{ml})$ for $6 \mathrm{~h}$. The results showed that TNF- $\alpha$ increased both ICAM-1 and VCAM-1 expression. This increase was significantly suppressed by honokiol from $20 \mu \mathrm{M}$, or $5 \mu \mathrm{M}$, respectively, suggesting that honokiol regulates the TNF- $\alpha$-induced expression of VCAM-1 more effectively than that of ICAM-1 (Fig. 2).

Honokiol inhibited the TNF- $\alpha$-stimulated adhesion of T98G glioblastoma cells to ECs. Following the study of the effect of honokiol on ICAM-1 and VCAM-1 expression after TNF- $\alpha$ stimulation, the effect of honokiol on the adhesion of cancer cells to HUVECs was investigated. Adhesion of T98G cells to HUVECs stimulated with TNF- $\alpha$ at $10 \mathrm{ng} / \mathrm{ml}$ for $6 \mathrm{~h}$ was dramatically increased compared to unactivated HUVECs. By contrast, treatment of the HUVECs with 5 to $50 \mu \mathrm{M}$ honokiol for $24 \mathrm{~h}$ before TNF- $\alpha$ stimulation resulted in a significant reduction of T98G cells adhering to ECs (Fig. 3).

Honokiol effectively prevented T98G cell invasion. Cancer cell invasion is important during the formation of distant metas- 
A

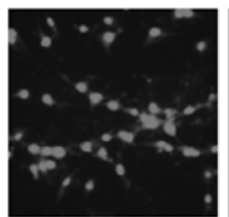

Control

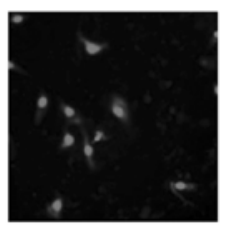

Honokiol

$10 \mu \mathrm{M}$

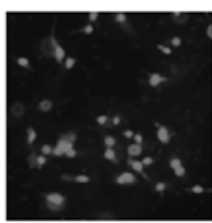

Honokiol

$1 \mu \mathrm{M}$

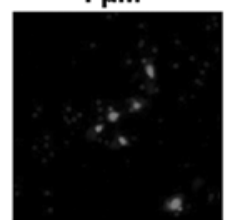

Honokiol

$20 \mu \mathrm{M}$

B

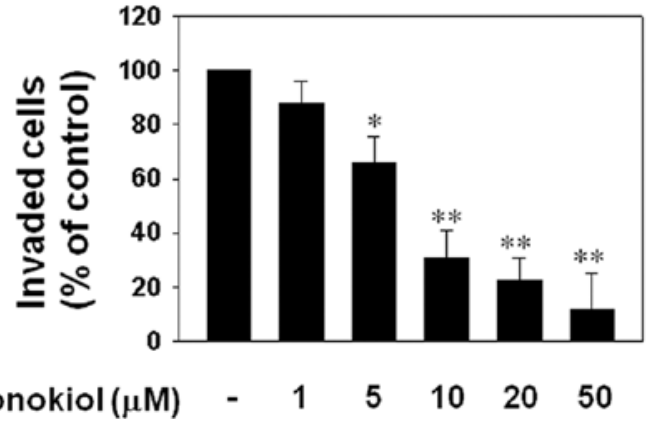

Figure 4. The effect of honokiol on the invasion of T98G cells. Cells were treated with varying doses of honokiol for $24 \mathrm{~h}$. Cells were collected and added to the Matrigel-coated transwell upper chamber as described in Material and methods. RPMI media containing 10\% FBS was added to the lower chambers and the invasion chambers were incubated for $24 \mathrm{~h}$ at $37^{\circ} \mathrm{C}$. The noninvasive cells that remained on the upper surface of the insert membranes were removed by scrubbing. (A) The cells that had invaded across the Matrigel-coated transwell membrane were stained with DAPI, and (B) the cells were counted under the light microscope. (B) Data represent the mean \pm SD of three separate experiments performed in triplicate. Significance compared with control, ${ }^{*} \mathrm{P}<0.05,{ }^{* *} \mathrm{P}<0.01$.

tases. Therefore, an in vitro invasion assay was performed to assess whether honokiol could inhibit glioblastoma invasion. T98G cells not treated with honokiol exhibited significant migration across a transwell membrane; by contrast, treatment with 5 to $50 \mu \mathrm{M}$ honokiol significantly inhibited cancer cell invasion (Fig. 4).

Honokiol decreased cell viability of T98G glioblastoma cells in a dose-dependent manner. Subsequently, we examined the cell viabilities of HUVECs and T98G cells in response to honokiol. When HUVECs and T98G cells were treated with varying doses of honokiol $(1,5,10,20$ or $50 \mu \mathrm{M})$ for 24 h, honokiol significantly suppressed cell viability of T98G cells at doses of $10 \mu \mathrm{M}$ or more; $50 \mu \mathrm{M}$ of honokiol decreased cell viability of T98G cells by approximately 77\% (Fig. 5A). Although honokiol also decreased the cell viability of HUVECs, honokiol-mediated cytotoxicity was not significant at doses lower than $20 \mu \mathrm{M}$, and the $50 \mu \mathrm{M}$ dose was less toxic to HUVECs than to T98G cells (Fig. 5B).

Honokiol induced apoptotic cell death by increasing the Bax/ $B c l-2$ ratio. Fig. 5A shows that honokiol significantly induced
A

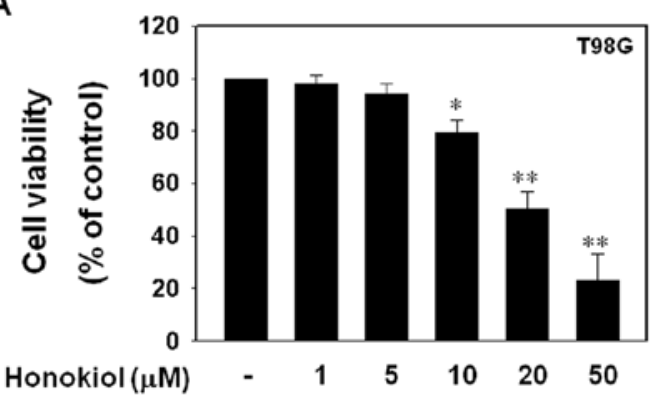

B

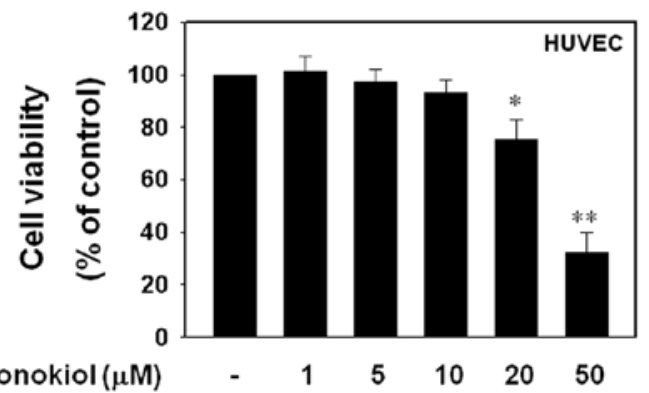

Figure 5. The effect of honokiol on the viability of (A) T98G glioblastoma cells and (B) HUVECs (B). Cells were treated with the indicated concentrations of honokiol for $24 \mathrm{~h}$. Cell viability was determined by the MTT assay as described in Materials and methods. Data are presented as the means \pm SD of three independent experiments. Significance compared with control, ${ }^{*} \mathrm{P}<0.05$, ${ }^{* * *} \mathrm{P}<0.01$.

T98G cell death from $10 \mu \mathrm{M}$, a lower dose than was toxic to HUVECs. To confirm that honokiol-induced cytotoxicity was due to the induction of apoptotic cell death in T98G cells, we performed a TUNEL assay and also assayed the levels of the anti-apoptotic protein, Bcl-2, and the pro-apoptotic protein, Bax, by western blot analysis. Cells were treated with honokiol (toxic doses; 10, 20 or $50 \mu \mathrm{M}$ ) for $24 \mathrm{~h}$, and TUNEL-positive cells were determined as described in Materials and methods. As shown in Fig. 6, honokiol effectively increased the number of TUNEL-positive cells at 10,20 and $50 \mu \mathrm{M}$, suggesting that honokiol-induced cytotoxicity was due to the induction of apoptotic cell death. Moreover, western blot analysis showed that honokiol significantly increased pro-apoptotic Bax protein levels and decreased anti-apoptotic Bcl-2 levels in T98G cells at doses of $10 \mu \mathrm{M}$ or more (Fig. 7), corresponding to the honokiol-induced cell death that also occurs at doses of $10 \mu \mathrm{M}$ or more. These results suggest that honokiol induces apoptotic cell death in glioblastoma cells through the upregulation of the $\mathrm{Bax} / \mathrm{Bcl}-2$ ratio.

\section{Discussion}

This study showed that honokiol, an active component isolated from the herb Magnolia officinalis, exerts anticancer effects in human glioblastoma T98G cells through the regulation of adhesion molecules and the induction of apoptotic cell death. In addition, we suggested that honokiol induces apoptotic cell death in glioblastoma cells through the upregulation of the $\mathrm{Bax} / \mathrm{Bcl}-2$ ratio and blocks glioblastoma cell invasion 


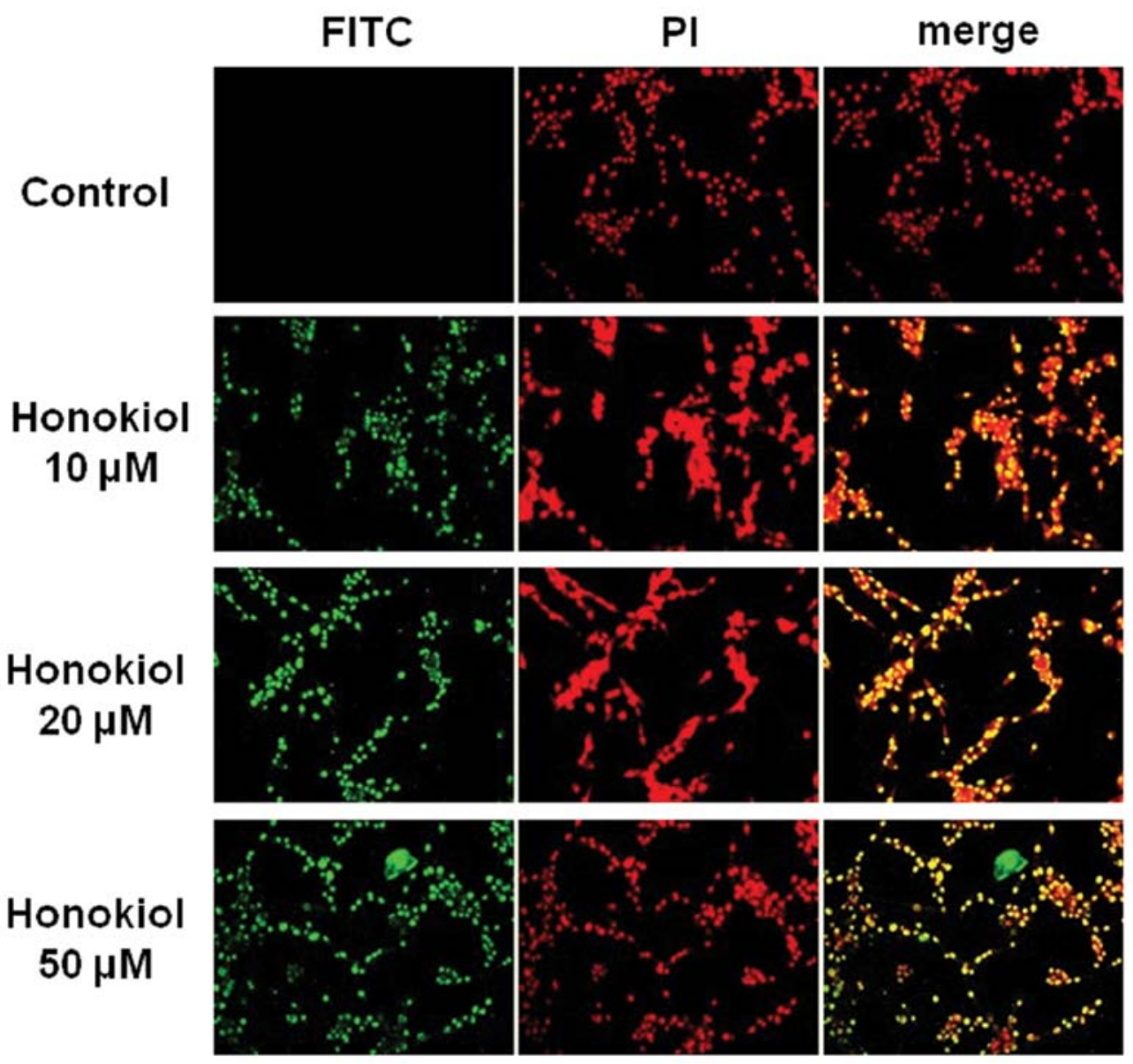

Figure 6. Induction of apoptosis by honokiol in T98G cells. Cells were treated with honokiol for 24 h and apoptotic cells were identified by a TUNEL assay as described in Materials and methods. The results were confirmed by repeated experiments.

A

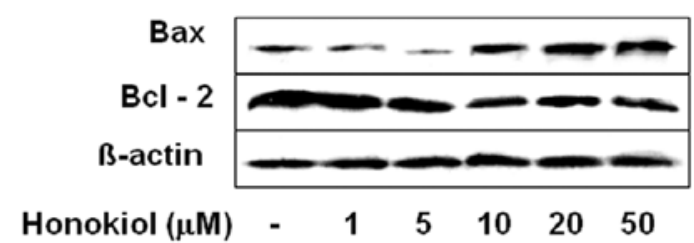

B

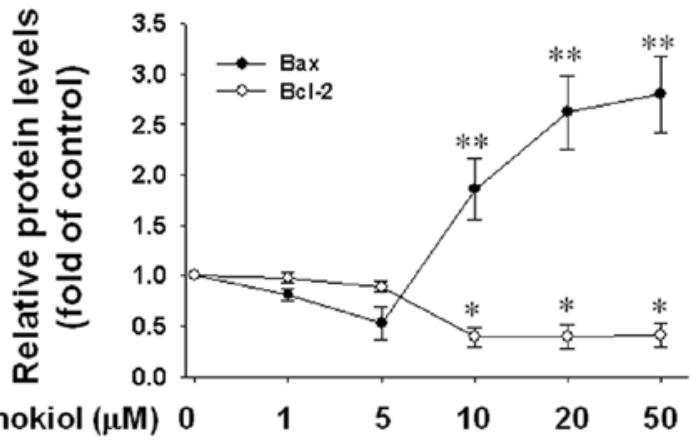

Figure 7. The effect of honokiol on the level of the anti-apoptotic protein Bcl-2, or the pro-apoptotic protein, Bax. Cells were treated with various concentrations of honokiol $(1,5,10,20$, or $50 \mu \mathrm{M})$ for $24 \mathrm{~h}$, and (A) the levels of Bcl-2 and Bax were determined by western blot analysis. (B) Bar graph shows densitometric determination of the level of Bcl-2 and Bax. Significance compared with honokiol, ${ }^{*} \mathrm{P}<0.05,{ }^{* *} \mathrm{P}<0.01$ through regulation of adhesion molecules such as ICAM-1 and VCAM-1 (Fig. 8).

As mentioned in the Introduction, glioblastoma is one of the most lethal and common malignant brain tumors in humans. Due to its tendency to diffusely infiltrate various regions of the normal brain, complete surgical removal is impossible, leading to a poor prognosis. One chemotherapeutic strategy is to aim at altering the biological properties of the cancerous cells to encourage their apoptosis or to block their invasion into other regions. Apoptosis is a physiological mode of cell death that can be selectively triggered by cells in response to a stimulus. Therefore, the induction of apoptosis is a key target of anticancer drugs. Apoptotic machinery is composed of dozens or more anti-apoptotic and pro-apoptotic proteins. The balance of anti-apoptotic and pro-apoptotic proteins contributes to the balance of cell growth and cell death. Bax, a pro-apoptotic protein, is normally found as a monomer in the cytosol of non-apoptotic cells. In response to apoptotic stimuli, Bax oligomerizes and translocates to the outer mitochondrial membrane (32), where it induces mitochondrial membrane permeabilization (33) and cytochrome $c$ release (34). Overexpression of the anti-apoptotic protein, $\mathrm{Bcl}-2$, has been found to stabilize the outer membrane and prevent the release of cytochrome $c$ following a variety of insults. In this study, honokiol dramatically increased the levels of the pro-apoptotic protein, Bax, and significantly 


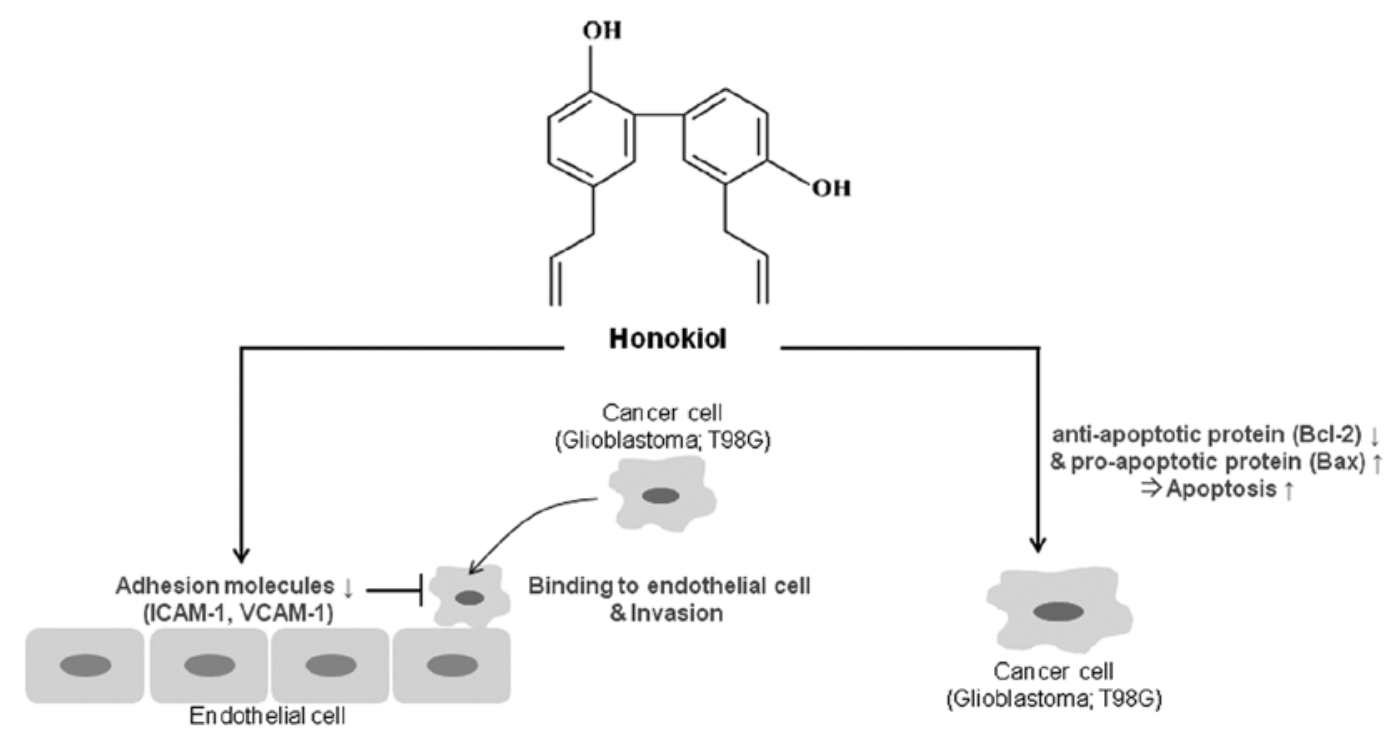

Figure 8. Proposed model for the anticancer effect of honokiol in glioblastoma T98G through the regulation of adhesion molecules and the induction of apoptosis.

decreased the levels of anti-apoptotic protein, Bcl-2, in T98G glioblastoma cells, suggesting that the honokiol's apoptotic potential is directly related to its ability to alter the ratio of pro-apoptotic to anti-apoptotic proteins in targeted cells.

With regard to invasion of cancer cells, a great deal of evidence suggests that CAMs may be associated with invasion and metastasis in a variety of human malignancies. This study demonstrated that $10 \mathrm{ng} / \mathrm{ml} \mathrm{TNF}-\alpha$ significantly induced ICAM-1 and VCAM-1 expression in HUVECs and that this induction was dramatically inhibited by honokiol. Additionally, honokiol significantly reduced the TNF- $\alpha$ mediated adhesion of cancer cells to ECs, which may be due to the inhibition of ICAM-1 and VCAM-1 expression. Interestingly, in this study, the lower doses ( $5 \mu \mathrm{M}$ or lower) of honokiol more effectively inhibited the increase in VCAM-1 levels induced by TNF- $\alpha$ than the increase in ICAM-1 levels (Fig. 2). According to previous studies, VCAM-1 plays a more important role than ICAM-1 in cancer metastasis $(35,36)$. Moreover, honokiol is less toxic to HUVECs than to T98G cells at the doses of 5 or $10 \mu \mathrm{M}$ while honokiol inhibits VCAM-1 expression or is toxic to T98G cells at these doses. Thus, honokiol may have a beneficial effect in the treatment of cancer.

Although some drugs show promise in treating cancers, there is a limitation to their use against brain tumors due to the BBB and the BCSFB. The BBB and the BCSFB are composed of capillary endothelial cells connected by tight junctions. Their main function as physical and active barriers is to restrict and regulate the penetration of compounds into and out of the brain to maintain brain homeostasis. Recently, Wang et al (17) reported that honokiol crosses the BBB and the BCSFB and contributes to antitumor activity in the brain. For this reason, honokiol has been used as an herbal medicine to treat nervous disorders $(7,10)$. Taken together, our study suggests that honokiol might be a potential therapeutic strategy against brain tumors such as glioblastoma.

\section{Acknowledgements}

This study was supported by the Basic Science Research Program through the National Research Foundation of Korea (NRF) funded by the Ministry of Education, Science and Technology (2011-0006200).

\section{References}

1. Wen PY and Kesari S: Malignant gliomas in adults. N Engl J Med 359: 492-507, 2008.

2. Sehgal A: Molecular changes during the genesis of human gliomas. Semin Surg Oncol 14: 3-12, 1998.

3. Shapiro WR: Current therapy for brain tumors: back to the future. Arch Neurol 56: 429-432, 1999.

4. Chang HM and But PH: Pharmacology and applications of Chinese Materia Medica. Vol 1. World Scientific Publishers, Singapore, pp878-880, 1986.

5. Haraguchi $\mathrm{H}$, Ishikawa $\mathrm{H}$, Shirataki $\mathrm{N}$ and Fukuda $\mathrm{A}$ : Antiperoxidative activity of neolignans from magnolia obovata. J Pharm Pharmacol 49: 209-212, 1997.

6. Kuribara H, Stavinoha WB and Maruyama Y: Behavioural pharmacological characteristics of honokiol, an anxiolytic agent present in extracts of Magnolia bark, evaluated by an elevated plus-maze test in mice. J Pharm Pharmacol 50: 819-826, 1998.

7. Maruyama Y, Kuribara H, Morita M, Yuzurihara M and Weintraub ST: Identification of magnolol and honokiol as anxiolytic agents in extracts of saiboku-to, an oriental herbal medicine. J Nat Prod 61: 135-138, 1998.

8. Kuribara H, Stavinoha WB and Maruyama Y: Honokiol, a putative anxiolytic agent extracted from magnolia bark, has no diazepam-like side-effects in mice. J Pharm Pharmacol 51: 97-103, 1999.

9. Kuribara H, Kishi E, Kimura M, Weintraub ST and Maruyama Y: Comparative assessment of the anxiolytic-like activities of honokiol and derivatives. Pharmacol Biochem Behav 67: 597-601, 2000 .

10. Watanabe K, Watanabe H, Goto Y, Yamaguchi M, Yamamoto N and Hagino K: Pharmacological properties of magnolol and honokiol extracted from Magnolia officinalis: central depressant effects. Planta Med 49: 103-108, 1983.

11. Liou KT, Shen YC, Chen CF, Tsao CM and Tsai SK: Honokiol protects rat brain from focal cerebral ischemia-reperfusion injury by inhibiting neutrophil infiltration and reactive oxygen species production. Brain Res 992: 159-166, 2003. 
12. Hibasami H, Achiwa Y, Katsuzaki H, Imai K, Yoshioka K, Nakanishi K, Ishii Y, Hasegawa M and Komiya T: Honokiol induces apoptosis in human lymphoid leukemia molt 4B cells. Int J Mol Med 2: 671-673, 1998.

13. Yang SE, Hsieh MT, Tsai TH and Hsu SL: Downmodulation of Bcl-X $\mathrm{L}_{\mathrm{L}}$, release of cytochrome $c$ and sequential activation of caspases during honokiol induced apoptosis in human squamous lung cancer $\mathrm{CH} 27$ cells. Biochem Pharmacol 63: 1641-1651, 2002.

14. Wang T, Chen F, Chen Z, Wu YF, Xu XL, Zheng S and Hu X: Honokiol induces apoptosis through $\mathrm{p} 53$-independent pathway in human colorectal cell line RKO. World J Gastroenterol 10: 2205-2208, 2004.

15. Hirano T, Gotoh M and Oka K: Natural flavonoids and lignans are potent cytostatic agents against human leukemic HL-60 cells. Life Sci 55: 1061-1069, 1994.

16. Crane C, Panner A, Pieper RO, Arbiser J and Parsa AT: Honokiolmediated inhibition of PI3K/mTOR pathway: a potential strategy to overcome immunoresistance in glioma, breast, and prostate carcinoma without impacting T cell function. J Immunother 32 585-592, 2009.

17. Wang X, Duan X, Yang G, Zhang X, Deng L, Zheng H, Deng C, Wen J, Wang N, Peng C, Zhao X, Wei Y and Chen L: Honokiol crosses $\mathrm{BBB}$ and $\mathrm{BCSFB}$, and inhibits brain tumor growth in rat 9L intracerebral gliosarcoma model and human U251 xenograft glioma model. PLoS One 6: e18490, 2011.

18. Fox SB, Turner GD, Gatter KC and Harris AL: The increased expression of adhesion molecules ICAM-3, E-selectin and P-selectins on breast cancer endothelium. J Pathol 177: 369-376, 1995.

19. Christiansen I, Sundstrom C, Enblad G and Totterman TH: Soluble vascular cell adhesion molecule-1 (sVCAM-1) is an independent prognostic marker in Hodgkin's disease. Br J Haematol 102: 701-709, 1998.

20. Christiansen I, Sundstrom C and Totterman TH: Elevated serum levels of soluble vascular cell adhesion molecule-1 (sVCAM-1) closely reflect tumour burden in chronic B-lymphocytic leukaemia. Br J Haematol 103: 1129-1137, 1998.

21. Wang X, Clowes C, Duarte R and Pu QQ: Serum ICAM-1 concentrations following conventional dose consolidation chemotherapy for acute myeloid leukemia and after high dose chemotherapy with autologous haematopoietic stem cell rescue. Int J Oncol 17: 591-595, 2000.

22. Maeda K, Kang SM, Sawada T, Nishiguchi Y, Yashiro M, Ogawa Y, Ohira M, Ishikawa T and Hirakawa YS, Chung CK: Expression of intercellular adhesion molecule-1 and prognosis in colorectal cancer. Oncol Rep 9: 511-514, 2002.

23. Becker JC, Dummer R, Hartmann AA, Burg G and Schmidt RE: Shedding of ICAM-1 from human melanoma cell lines induced by IFN-gamma and tumor necrosis factor-alpha. Functional consequences on cell-mediated cytotoxicity. J Immunol 147: 4398-4401, 1991.
24. Osborn L, Hession C, Tizard R, Vassallo C, Luhowskyj S, Chi-Rosso G and Lobb R: Direct expression cloning of vascular cell adhesion molecule-1, a cytokine-induced endothelial protein that binds to lymphocytes. Cell 59: 1203-1211, 1989.

25. Springer TA: Traffic signal for lymphocyte recirculation and leukocyte emigration: the multistep paradigm. Cell 76: 301-314, 1994.

26. Kim HJ, Tsoy I, Park JM, Chung JI, Shin SC and Chang KC Anthocyanins from soybean seed coat inhibit the expression of TNF- $\alpha$-induced genes associated with ischemia/reperfusion in endothelial cell by NF- $\mathrm{BB}$-dependent pathway and reduce rat myocardial damages incurred by ischemia and reperfusion in vivo. FEBS Lett 580: 1391-1397, 2006.

27. Nizamutdinova IT, Oh HM, Min YN, Park SH, Lee MJ, Kim JS Yean MH, Kang SS, Kim YS, Chang KC and Kim HJ: Paeonol suppresses intercellular adhesion molecule-1 expression in tumor necrosis factor- $\alpha$-stimulated human umbilical vein endothelial cells by blocking $\mathrm{p} 38$, ERK and nuclear factor- $\kappa \mathrm{B}$ signaling pathways. Int Immunopharmacol 7: 343-350, 2007.

28. Zhang GJ and Adachi I: Serum levels of soluble intercellular adhesion molecule-1 and E-selectin in metastatic breast carcinoma: correlations with clinicopathological features and prognosis. Int J Oncol 14: 71-77, 1999.

29. Thompson EW and Price JT: Mechanisms of tumour invasion and metastasis: emerging targets for therapy. Expert Opin Ther Targets 6: 217-233, 2002.

30. Balkwill $\mathrm{F}$ and Mantovani A: Inflammation and cancer: back to Virchow? Lancet 357: 539-545, 2001.

31. Nizamutdinova IT, Lee GW, Lee JS, Cho MK, Son KH, Jeon SJ, Kang SS, Kim YS, Lee JH, Seo HG, Chang KC and Kim HJ. Tanshinone I suppresses growth and invasion of human breast cancer cells, MDA-MB-231, through regulation of adhesion molecules. Carcinogenesis 29: 1885-1892, 2008.

32. Goping IS, Gross A, Lavoie JN, Nguyen M, Jemmerson R, Roth K, Korsmeyer SJ and Shore GC: Regulation targeting of BAX to mitochondria. J Cell Biol 143: 207-215, 1998.

33. Kuwana T and Newmeyer DD: Bcl-2 family proteins and the role of mitochondria in apoptosis. Curr Opin Cell Biol 15: 691-699. 2003.

34. Wei MC, Zong WX, Cheng EH, Lindsten T, Panoutsakopoulou V, Ross AJ, Roth KA, MacGregor GR, Thompson CB and Koresmeyer SJ: Proapoptotic BAX and BAK: a requisite gateway to mitochondrial dysfunction and death. Science 292: 727-730, 2001.

35. Klemke M, Weschenfelder T, Konstandin MH and Samstag Y: High affinity interaction of integrin alpha4beta1 (VLA-4) and vascular cell adhesion molecule 1 (VCAM-1) enhances migration of human melanoma cells across activated endothelial cell layers. J Cell Physiol 212: 368-374, 2007.

36. Wu TC: The role of vascular cell adhesion molecule-1 in tumor immune evasion. Cancer Res 67: 6003-6006, 2007. 